\title{
Performance of Beams Made of Low-cost Self-compacting Concrete in an Aggressive Environment
}

\author{
M. A. Safan
}

\begin{abstract}
Self-Compacting Concrete mixes (SCC) incorporating silica fume, fly ash and dolomite powder were used in casting two groups of beams. The beams in one group were stored in an open environment, while those in the other group were subjected to salt attack and successive wet/drying cycles. The beams were stored for about one year under a sustained load. The structural performance of the stored beams was evaluated by testing the specimens under four-point loading until failure. The results indicated that the low-cost SCC mixes showed comparable structural behavior with respect to the corresponding control mixes in a normal environment. Different SCC mixes in a corrosive environment yielded a different structural performance, depending on the composition of the fillers.
\end{abstract}

Keywords: corrosion, self-compacting concrete, silica fume, fly ash, dolomite powder, harsh.

\section{Introduction}

Steel Reinforcements are used in concrete members to resist tensile stresses and to provide the concrete structure with the required structural integrity. Unfortunately, the steel reinforcement has a natural tendency to corrode, returning to its stable state as an iron ore [1]. Steel corrosion is considered the leading cause of deterioration in concrete structures. Corrosion in progress results in rust occupying a greater volume and thus exerting stress on the surrounding concrete. Estimates of the expansive stress exerted due to rust were reported to vary from 32 to $500 \mathrm{MPa}[2]$. Such a substantial stress causes concrete to crack, delaminate and finally spall. Loss of the concrete-steel bond and reduction of the effective reinforcement area put the integrity and safety of the structure seriously into question.

Corrosion is an electrochemical process involving the flow of electrons and soluble metal cations $\left(\mathrm{Fe}^{2+}\right)$ that migrate through the concrete pore water to combine with hydroxyl ions $\left(\mathrm{OH}^{-}\right)$to form iron hydroxide $\left(\mathrm{Fe}(\mathrm{OH})_{2}\right)$ or rust. The amount and rate of the corrosion depend largely on the solubility of the metal cations, which is influenced by temperature, by the $\mathrm{pH}$ of the surrounding medium, and by the humidity of concrete. Sound concrete has a pH of 12 to 13 [3]. This high alkalinity results in the formation of a tight film of iron oxide, which serves as a passive protection against corrosion. The passive film reduces the corrosion rate to an insignificant level, typically $0.2 \mu \mathrm{m}$ per year. This rate is increased by up to 1000 times if the passive layer is destroyed [1].

The passive protection is subject to destruction due to the penetration of chloride ions when concrete serves in a salt-rich environment. Dissolved chlorides can permeate slowly through sound concrete, or can reach the steel more rapidly through cracks. As expected, the risk of corrosion increases as the chloride content increases. According to ACI 318 [4], the maximum content for water-soluble chloride from the constituting materials is $0.15 \%$ by weight of the concrete for reinforced concrete exposed to chloride in service and $0.3 \%$ by weight of the concrete for protected concrete. It is interesting to note that chlorides are directly responsible for the initiation of corrosion, and do not influence the future corrosion rate.

The natural protection of concrete against corrosion is affected by carbonation, which reduces the $\mathrm{pH}$ of concrete due to the reaction of carbon dioxide from the air and calcium hydroxide. The $\mathrm{pH}$ can be as low as 8.5 due to this reaction, and the passive layer becomes unstable [5]. In addition, carbonation allows for a much smaller chloride corrosion threshold. It is reported that 7000 to $8000 \mathrm{ppm}$ of chlorides are required to initiate corrosion when the concrete $\mathrm{pH}$ is 12 to 13 , while only $100 \mathrm{ppm}$ concentration is needed when the $\mathrm{pH}$ is 10 to 12 [6]. However, carbonation reactions are slow, and carbonation proceeds at a rate up to $1.0 \mathrm{~mm}$ pear year in high quality concrete characterized by low permeability, high cement content and a low water/cement ratio. The carbonation rate depends on the relative humidity of the concrete, and the highest rates occur in concretes with 50-75 percent relative humidity, so that the carbonation rates are insignificant in dry as well as water-saturated concrete [7].

The above literature concerning corrosion mechanisms, environment and triggers has clearly demonstrated that concrete quality and design practices 
may be considered as the first defense against corrosion. First, quality concretes are produced with well-proportioned quality materials, and they typically have low water/cement ratios, are well compacted and well cured. These practices reduce the permeability and porosity of concrete and thus slow down the penetration of chloride ions and carbonation. The water/cement ratios can be lowered by simply increasing the cement content, using waterreducing admixtures and using fly ashes. Further, the use of micro-silica can help to produce almost impermeable concrete [8]. Second, design practices for concrete structures specify the amount of steel reinforcements that will keep the cracks tight. ACI 318 [4] specifies a maximum crack width of $0.33 \mathrm{~mm}$ for exterior exposure under service loads, and $0.4 \mathrm{~mm}$ for interior exposure under service loads. Another important factor is to specify minimum concrete covers depending on exposure conditions in order to delay the onset of corrosion by extending the time required for carbonation and penetrating chlorides to reach the steel reinforcement [9].

It was interesting to find that self-compacting concrete (SCC) was initially named high-performance concrete. SCC was more used worldwide to describe durable concrete with a low water/cement ratio [10]. This new type of concrete, proposed by Okamura in 1986, was indented to be selfcompactable in the fresh state, free from initial defects in the early age, and durable after hardening [11]. The intrinsic properties of SCC involve high deformability of the mortar and resistance to segregation when concrete flows through confining steel rebars. According to Okamura and Ozawa [12], these properties can be achieved by utilizing limited aggregate content, a lower water/powder ratio and by using superplastizers. SCC mixes typically incorporate high fractions of cements and fine materials such as silica fume (SF), fly ash (FA), granulated blast furnace slag (GBFS), limestone powder, etc. Combining finely divided powders, admixtures, and Portland cement can enhance the behavior of SCC in terms of filling ability, passing ability, and stability. The main target is to enhance the grain-size distribution and particle packing, thus ensuring greater cohesiveness [13].

Silica fume is a by-product resulting from the operation of electric arc furnaces used to reduce high purity quartz to produce silicon and ferrosilicon alloys. Silica fume consists of extremely fine spherical particles of amorphous silicon dioxide with an average particle diameter that is about $1 / 100$ of the average particle diameter of cement. Due to its extreme fineness, silica fume has a pronounced effect on the fresh and hardened properties of concrete due to physical effects and pozzolanic reactions. The physical effects include reduced bleeding and greater co- hesiveness, which directly influence the properties of hardened concrete [8]. According to Mindess [14], silica fume increases the strength of hardened concrete by increasing the strength of the transition zone between the cement paste and coarse aggregates. Through pozzolanic reactions, silica fume reacts with calcium hydroxide $(\mathrm{CH})$ resulting from the cement hydration process, producing calcium silicate hydrate (CSH). Relatively more $\mathrm{CH}$ forms in the transition zone than through the paste. $\mathrm{CH}$ crystals tend to decrease the strength of cement materials, as they are normally large, strongly oriented parallel to the aggregate surface and weaker than CSH. Concern has been raised regarding a reduction in the $\mathrm{pH}$ of the pore fluid by the consumption of $\mathrm{CH}$, and the effect of any such reduction on the passivation of the reinforcing steel. At the levels of silica fume dosage typically used in concrete, the reduction of $\mathrm{pH}$ is not large enough to be of concern. For corrosion protection purposes, the increased electrical resistivity and the reduced diffusivity to chloride ions are believed to be more significant than any reduction in pore solution $\mathrm{pH}[8]$.

Fly ash is a by-product of coal combustion in electric power plants. Depending on the chemical composition, fly ashes are classified as class F: low-lime ashes with pozzolanic properties normally produced from anthracite or bituminous coal, and class C: highlime ashes with pozzolanic and cementitious properties normally produced from lignite or subbituminous coal. According to ASTM C618 [15], the sum of $\mathrm{SiO}_{2}, \mathrm{Al}_{2} \mathrm{O}_{3}$ and $\mathrm{Fe}_{2} \mathrm{O}_{3}$ should be greater than $70 \%$ to classify the ash as type $\mathrm{F}$, and greater than $50 \%$ to classify it as type C. Fly ash is used to improve the workability of fresh concrete, reduce the temperature rise during initial hydration, improve resistance to sulfates, reduce expansion due to alkali-silica reaction, and increase both the strength and the durability of hardened concrete. Fly ashes suitable for use in concrete should be fine enough so that no more than $34 \%$ of the particles are retained on a $45 \mu \mathrm{m}$ (No. 325) sieve, in accordance with ASTM C618 requirements. The properties of fresh concrete containing fly ash are improved in terms of reduced bleeding, as a greater surface area of solid particles is provided at lower water content for a specified workability. Unlike silica fume, the pozzolanic reaction of fly ash continues over several years if the concrete is kept moist. Thus, concrete containing fly ash with lower early strength would be expected to have equivalent or higher strength at 28 days and at later ages [16].

Dolomite powder was used as a filler in the current work. However, limestone powders are most frequently used in the SCC mixes reported in the literature. It is expected that the powders obtained when cutting or sieving natural rocks would give similar physical effects depending on shape, size and surface 
texture characteristics. Both limestone and dolomite are carbonate rocks. Pure limestone is mainly composed of calcium oxide and carbon dioxide. When about 20 percent of magnesium oxide is introduced, we obtain high quality dolomite stone that is stronger and harder than limestone. Ye, et al. [17] explored the hydration and the microstructure of cementitious pastes of typical composition for ordinary, high performance, and self-compacting concrete, and reported that limestone powders do not participate in the chemical reactions during hydration.

By definition and by composition, SCC is expected to provide a protective environment against corrosion with regard to its low water/powder ratio, reduced bleeding and reduced permeability due to the use of extremely fine materials. The corrosion resistance parameters of SCC have been investigated by many authors. Yazici [18] investigated the chloride penetration of SCC mixes incorporating silica fume and high-volume class $\mathrm{C}$ fly ash. It was reported that incorporating FA and/or SF was very effective for improving resistance to chloride penetration. The penetration depth in the control mix with only Portland cement was $19 \mathrm{~mm}$ after 90 cycles, while this depth was only $9.5 \mathrm{~mm}$ in SCC with $60 \% \mathrm{FA}$ and $10 \% \mathrm{SF}$ replacement. The potentials of SCC durability and the corrosion parameters in terms of chloride penetration, oxygen permeability and accelerated carbonation were addressed by Assié et al. [19] for both SCC and vibrated concrete (VC). They used CEMII/A-LL 32.5R and CEMI 52.5N cements, which are typically used for low-strength and high-strength concrete, respectively. The SCC mixes were proportioned using limestone filler to replace fractions of the coarse aggregate. The results showed that SCC mixes were more resistant than $\mathrm{VC}$ to oxygen permeability, while the chloride penetration and carbonation amounts were similar in both SCC and VC mixes. Zhu and Bartos [20] investigated the permeation properties of SCC as durability measures utilizing FA and limestone fillers. It was emphasized that the permeation measures are strongly reflected by the type of filler. Saylev and Francois [21] investigated the influence of the steel-concrete interface on the corrosion of steel in terms of resistance to polarization and the corroded surface area. Interface defects related to gaps caused by bleeding, settlement and segregation of fresh concrete were more limited in SCC than in VC.

Despite the appealing characteristics and merits of self-compacting concrete, it is still classified as a special type of concrete. The wide spread of this type of concrete is restricted by the need to implement strict quality measures and by the relatively high cost of SCC mixes. A rational mix design should attempt to balance the cost and the structural efficiency of concrete in terms of durability and strength. It is however expected that SCC can be- come a conventionally-used material with a competitive cost, for two reasons. First, concrete developers believe that $21^{\text {st }}$ century concrete practice must be driven by considerations of durability rather than strength in order to build environmentally sustainable concrete structures [22]. Second, it is possible to invest in establishing ready-mix concrete plants even in small local communities, due to the continuously expanding market, and in this way quality production can be achieved. The cost-effectiveness of SCC was a matter of concern in many recent research works reported in the literature [23-25]. Mix economy is usually achieved by incorporating low-cost byproducts that may replace Portland cement as active and non-active fillers. The initial work presented by the author [25] dealt with attempts to produce lowcost SCC by using dolomite stone powder to replace significant amounts of cement and limiting the use of chemical admixtures to HRWR admixtures. The results indicated that it was possible to combine SF (10\% by weight of cement) either with FA (up to $40 \%$ by weight of cement) or with dolomite powder (up to $30 \%$ by weight of cement) to obtain SCC with a satisfactory level of compressive strength for structural concrete.

\section{Significance of the research}

Extensive research work is needed to explore the durability parameters of self-compacting concrete. The properties of hardened SCC can differ greatly, as the mixes usually incorporate different combinations of fines for technical and economic purposes. For this reason, studies addressing the influence of fine powders and combinations of fine powders on strength and durability are needed for the development of SCC mixes. The current work has investigated the corrosion protection provided by different SCC mixes containing different fillers. The test specimens were exposed to a corrosive environment while they were under service loading as simply supported beams. The beams were subjected to salt solutions and wet/drying cycles for about one year to accelerate corrosion, after which the beams were tested to failure to examine their structural behavior and address the apparent defects due to corrosion.

\section{Experimental study}

The experimental work included the manufacture of two sets of test beams. The beams in one set were stored for one year in an aggressive medium to accelerate corrosion, while those in the other set were stored protected from extreme exposure. The beams in the two sets were loaded during storage under service loading. Based on the results reported in an 
initial phase of the research [25], seven mixes were selected to produce SCC based on the compressive strength criterion. The selected mixes incorporated dolomite powder (DP) replacing up to $30 \%$ of the cement weight, along with either silica fume (SF) or fly ash (FA), which replaced $10 \%$ of the cement by weight. The chemical analysis of the fine materials that were used - including cement, silica fume, fly ash and dolomite powder - are reported in Table 1. The constituents of the selected SCC mixes are given in Table 2. In these mixes, the fine-to-coarse aggregate ratio was 1.13 , the total content of powders (cement and fillers) was $500 \mathrm{~kg} / \mathrm{m}^{3}$, the HRWR dosage was fixed at $10 \mathrm{~kg} / \mathrm{m}^{3}$ (2\% by weight of the powders). The water content was determined by a trial-and-error procedure to obtain a consistent mix with the required fresh rheological properties. Table 3 shows the compressive strength evaluated at 28 and 365 days, and the measured rheological properties.

Table 1: Chemical analysis of fine materials (\% by mass)

\begin{tabular}{|c|c|c|c|c|}
\hline Material & CEMI 52.5-N & Silica fume & Fly ash (F) & Dolomite Powder \\
\hline $\mathrm{SiO}_{2}$ & 21.3 & 93.2 & 49.0 & 0.83 \\
\hline $\mathrm{Fe}_{2} \mathrm{O}_{3}$ & 2.67 & 1.58 & 4.10 & 0.52 \\
\hline $\mathrm{Al}_{2} \mathrm{O}_{3}$ & 4.22 & 0.51 & 32.3 & 0.77 \\
\hline $\mathrm{CaO}$ & 62.3 & 0.20 & 5.33 & 28.5 \\
\hline $\mathrm{MgO}$ & 2.65 & 0.57 & 1.56 & 19.3 \\
\hline $\mathrm{K}_{2} \mathrm{O}$ & 1.00 & 0.53 & 0.54 & nd \\
\hline $\mathrm{Na}_{2} \mathrm{O}$ & 0.15 & 0.45 & 0.28 & nd \\
\hline $\mathrm{SO}_{3}$ & 3.20 & 0.22 & 0.16 & nd \\
\hline $\mathrm{CO}_{2}$ & nd & nd & 0.80 & 46.8 \\
\hline L.O.I & 1.80 & 2.62 & 1.25 & 43.2 \\
\hline
\end{tabular}

nd: not detected

Table 2: Concrete mix proportions

\begin{tabular}{ccccccccc}
\hline \multirow{2}{*}{ Mix } & \multicolumn{7}{c}{ Mix Constituents $^{\mathrm{a}}, \mathrm{kg} / \mathrm{m}^{3}$} & \multirow{2}{*}{$\mathrm{w} / \mathrm{p}$} \\
\cline { 2 - 7 } & cement & sand & dolomite & water & $\begin{array}{c}\text { silica } \\
\text { fume }\end{array}$ & fly ash & $\begin{array}{c}\text { dolomite } \\
\text { powder }\end{array}$ & \\
\hline M1 & 500 & 945 & 840 & 160 & - & - & - & 0.32 \\
M2 & 450 & 935 & 830 & 165 & - & - & 50 & 0.33 \\
M3 & 400 & 925 & 820 & 170 & - & - & 100 & 0.34 \\
M4 & 350 & 915 & 810 & 170 & 50 & - & 100 & 0.34 \\
M5 & 300 & 900 & 800 & 175 & 50 & - & 150 & 0.35 \\
M6 & 350 & 915 & 810 & 170 & - & 50 & 100 & 0.34 \\
M7 & 300 & 900 & 800 & 175 & - & 50 & 150 & 0.35 \\
\hline${ }^{a}$ superplasticizer dosage in all mixes $=10 \mathrm{~kg} / \mathrm{m}^{3}(2 \%$ by weight of powders $)$
\end{tabular}

Table 3: Rheological and hardened properties of SSC mixes

\begin{tabular}{ccccc}
\hline \multirow{2}{*}{ Mix } & \multicolumn{2}{c}{$f_{c y}(\mathrm{MPa})$} & \multicolumn{2}{c}{ rheological properties } \\
& 28-days & 365-days & slump flow $(\mathrm{mm})$ & V-funnel $t_{0}(\mathrm{sec})$. \\
\hline M1 & 33 & 36.5 & 710 & 6.2 \\
M2 & 32 & 34.0 & 675 & 6.0 \\
M3 & 28 & 31.0 & 660 & 5.3 \\
M4 & 33 & 36.0 & 600 & 5.3 \\
M5 & 31 & 33.0 & 590 & 5.0 \\
M6 & 29 & 32.0 & 650 & 5.0 \\
M7 & 28 & 31.0 & 630 & 5.2 \\
\hline
\end{tabular}




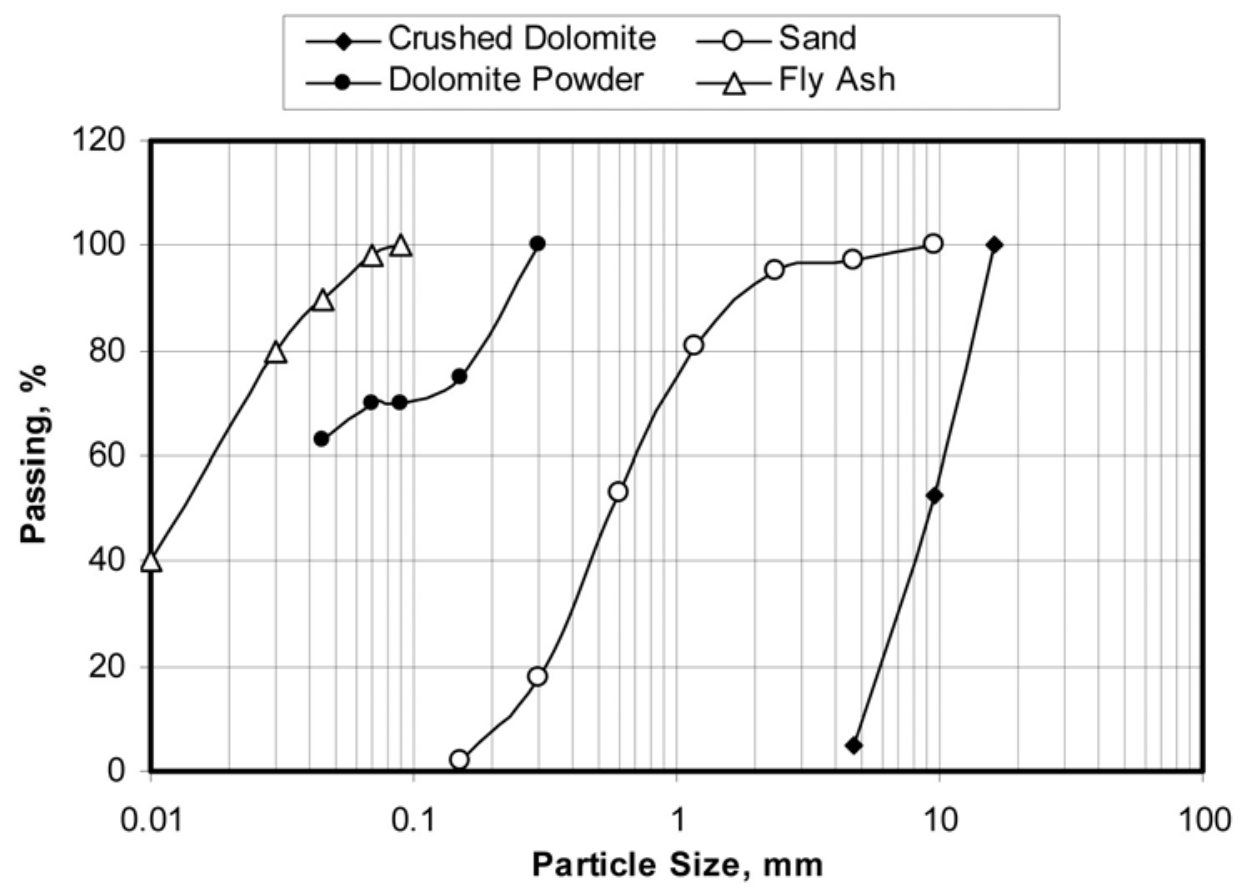

Fig. 1: Particle size distribution for aggregates, dolomite powder and fly ash


Fig. 2: Dimensions and reinforcements of a test beam

\section{Materials}

Cement type I $(42.5 \mathrm{~N})$ meeting the requirements of BS EN 197-1:2000 [26] was used. The specific gravity of the cement was 3.13 , and the initial setting time was 105 min. (28 percent water for standard consistency). Locally produced densified silica fume was delivered in 20-kg sacks. According to the manufacturer, the light-gray powder had a specific gravity of 2.2 , and a specific surface area of $17 \mathrm{~m}^{2} / \mathrm{gm}$. Imported class $\mathrm{F}$ fly ash meeting the requirements of ASTM C618 [15] was used. The average sum of $\mathrm{SiO}_{2}, \mathrm{Al}_{2} \mathrm{O}_{3}$ and $\mathrm{Fe}_{2} \mathrm{O}_{3}$ is 86 percent by weight, with a specific gravity of 2.1. The particle size distribution curve, Figure 1, shows that 90 percent by weight of the ash passes through a $45-\mu \mathrm{m}$ sieve. The dolomite powder was obtained from a local plant for ready-mix asphalt concrete. The production process includes drying the crushed dolomite used as coarse aggregate and sieving the aggregates to separate the different sizes. A small fraction of the powder that passes through sieve No. $50(300 \mu \mathrm{m})$ is used in the mix, while most of the powder is a by-product. The powder had a light brownish color, and a specific gravity of 2.72. Sieving six random samples of the powder showed that the average percentage passing through the $45-\mu \mathrm{m}$ sieve was 63 percent (Figure 1 ).

Natural siliceous sand having a fineness modulus of 2.63 and a specific gravity of 2.65 was used in the SCC mixes. Crushed dolomite with a maximum nominal size of $16 \mathrm{~mm}$ was used as coarse aggregate. The aggregate had a specific gravity of 2.65 and a crushing modulus of $19 \%$. The grading of the aggregates that were used is shown in Figure 1. A traditional sulfonated naphthalene formaldehyde condensate HRWR admixture conforming to ASTM C494 (types A and F) was used. The admixture is a brown liquid with a specific gravity of 1.18 . High tensile deformed steel rebars (nominal diameter $10 \mathrm{~mm}$ ) were used for tension reinforcement. The rebars had a yield strength of $553 \mathrm{MPa}$. Mild steel rebars were used for stirrups with a nominal diameter of $8 \mathrm{~mm}$ and yield strength of $380 \mathrm{MPa}$.

\section{Test specimens}

Preparation: Tight steel forms were used to cast fourteen test specimens with the dimensions and re- 
inforcement arrangement shown in Figure 2. Each concrete mix was used to cast two beams. The amount of tension and web reinforcement was adequate to ensure ductile failure under ultimate load. Six $150 \times 300 \mathrm{~mm}$ cylinders were cast to determine the compressive strength for each mix after 28 days and after one year of exposure. The test beams and the cylinder specimens were cured under a wet cloth for 7 days, after which they were left to dry in the laboratory atmosphere.

After 28 days, the test beams were loaded to a specified level as if the beams were under service flexure loading. Each two beams cast from the same mix were laid horizontal and parallel to each other with the tension side out. The two beams were tied by means of a 12-mm welded steel stirrup $50 \mathrm{~mm}$ away from the beam ends. A $100 \mathrm{kN}$ hydraulic jack was used to apply a concentrated load at mid span, while the end ties counteracted the acting load. Once a predetermined load level had been attained, two pieces of wood $(50 \times 50 \mathrm{~mm}$ cross section and $100 \mathrm{~mm}$ apart $)$ were used to maintain the deformed shape of the two opposite beams and the hydraulic jack was released. The loading sequence is illustrated in Figure 3.
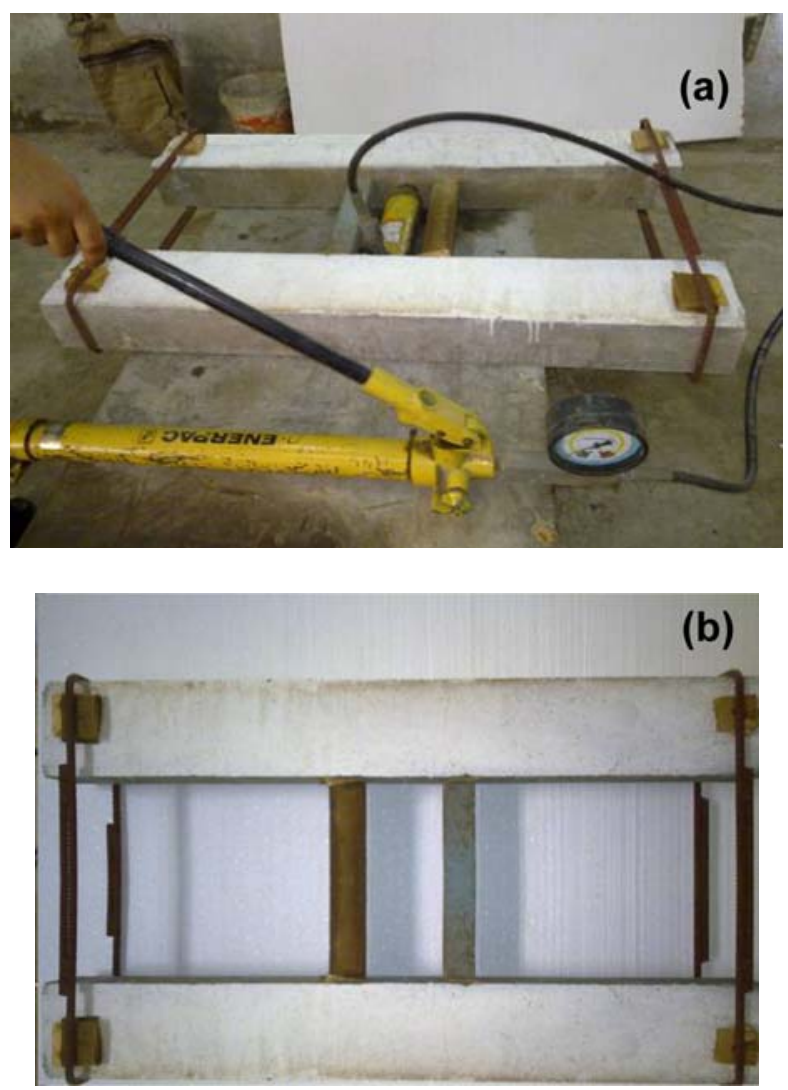

Fig. 3: Test beams tied and loaded at mid-span by means of a hydraulic jack: (a) Loading configuration, (b) Wooden struts keeping the deformed shape after releasing the hydraulic jack
The load applied by the hydraulic jack in this stage $\left(P_{s}\right)$ was the load causing the test beams to crack so that the length of the cracks would not exceed two thirds of the beam depth. This load was found to be $20 \mathrm{kN}$, and this value was about $47 \%$ of the nominal failure load $\left(P_{n}\right)$ estimated using the ACI 318 code [4] design equation:

$$
M_{n}=\rho f_{y}\left(1-0.59 \rho f_{y} / f_{c y}\right) b d^{2}
$$

in which $M_{n}$ is the nominal moment $\left(M_{n}=P_{n} L / 4\right.$, $L$ is the clear span $=900 \mathrm{~mm}), \rho$ is the reinforcement ratio $(\rho=0.012), f y$ is the yield strength of the tension reinforcement $(f y=553 \mathrm{MPa}), f c y$ is the 28-day cylinder compressive strength, $b$ is the width of the beam cross section $(b=100 \mathrm{~mm})$ and $d$ is the effective depth $(d=12.7 \mathrm{~mm})$. Table 4 reports the maximum crack width, which was measured using a microscope under the applied load $\left(P_{s}\right)$. The maximum measured crack width was $0.16 \mathrm{~mm}$, which is about one half of the maximum width permitted by the ACI 318 code for exposed elements.

Table 4: Maximum measured crack width under service load

\begin{tabular}{lc}
\hline Mix & Crack width $(\mathrm{mm})$ \\
\hline M1 & 0.14 \\
M2 & 0.14 \\
M3 & 0.16 \\
M4 & 0.14 \\
M5 & 0.14 \\
M6 & 0.16 \\
M7 & 0.16 \\
\hline
\end{tabular}

Exposure procedure: the test beams under a sustained load were closely arranged, as shown in Figure 4 . The upper beams were control beams that were kept dry during the whole course of exposure. On the other hand, the lower beams rested on the floor of a shallow basin containing an $\mathrm{NaCl}$ solution. The amount of the saline was sufficient to cover only $15 \mathrm{~mm}$ of the beam height. The concentration of the saline was adopted on the basis of the results reported in Ref. [1], showing that the corrosion rate of steel was at its maximum when the $\mathrm{NaCl}$ solution concentration was $7 \%$, which is about twice the $\mathrm{NaCl}$ concentration in seawater. This concentration of the $95 \%$ percent purity salt containing 15 percent water provided $34.000 \mathrm{mg} / \mathrm{l}$ of soluble chloride ions. This amount of ions represents $1.1 \%$ by weight of the cement in control mix M1, which means that the ion concentration was 7 times higher than the concentration allowed by the ACI 318 code [4] for elements in severe conditions. 

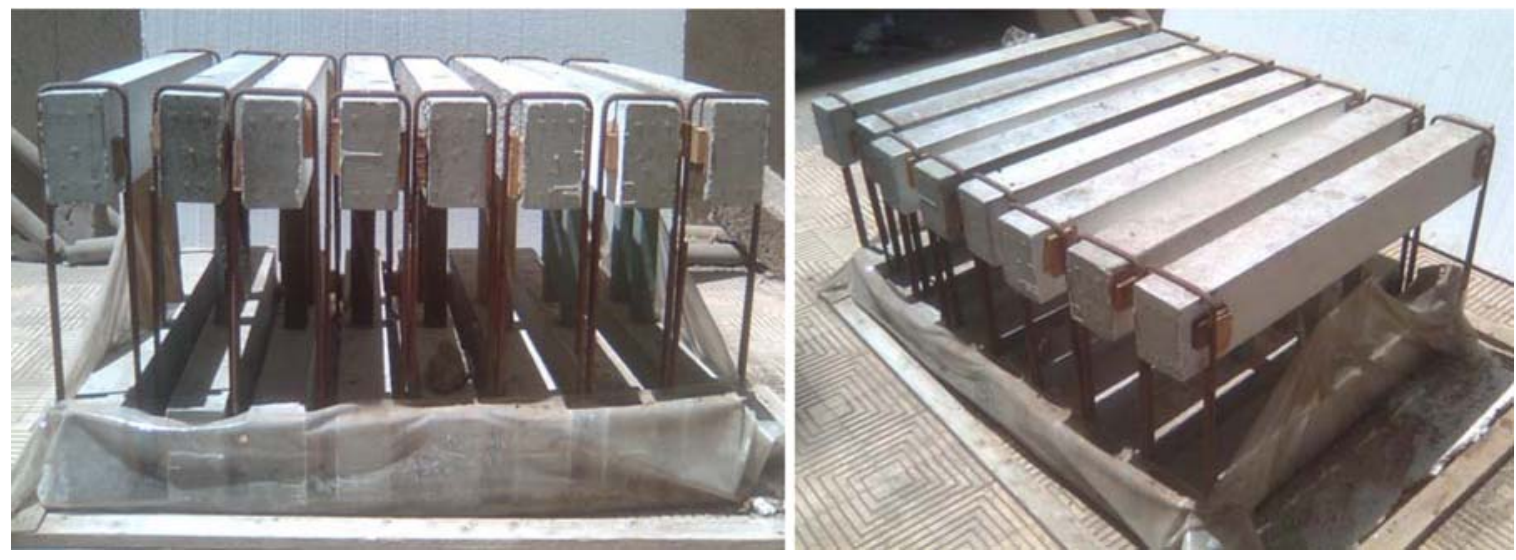

Fig. 4: Exposure of test beams in an open environment under a sustained load
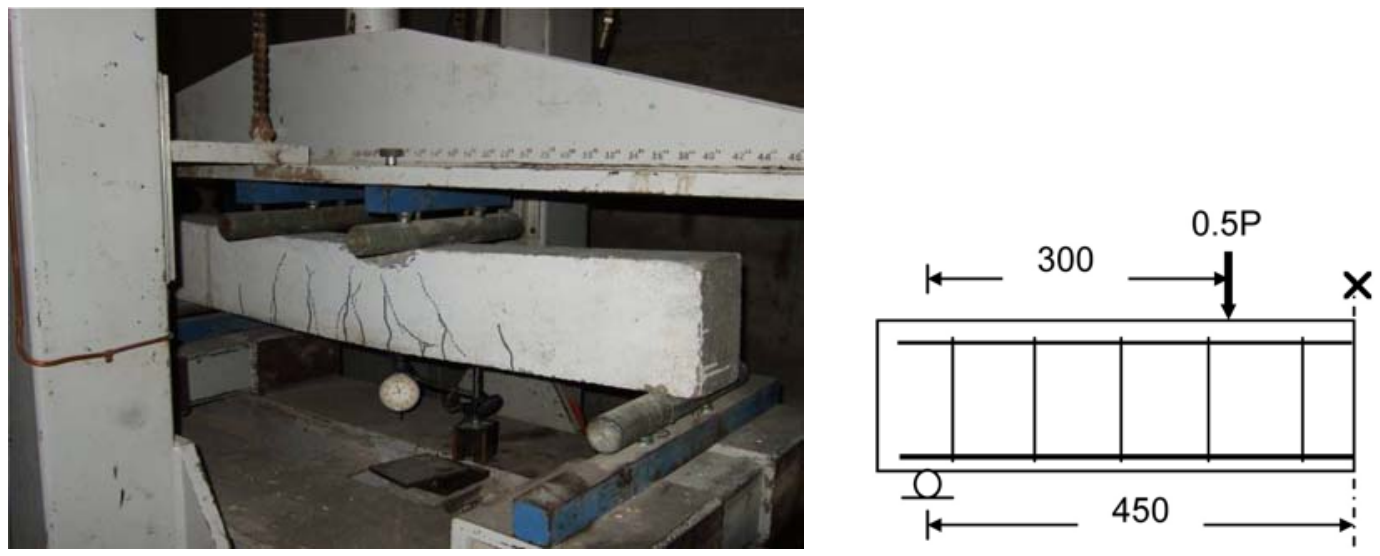

Fig. 5: Four-point bending test and loading configuration

The beams were stored in an open environment for 12 months. The lower beams attached to the saline underwent 12 wet/dry cycles. The beams were attached to the saline for 7 days, after which the saline was drained out and the lower beams were allowed to dry for 21 days. At the start of each cycle, the sustained load level was checked. The losses in the sustained load due to time-dependent effects were restored by reloading, using a hydraulic jack and repositioning the wooden struts. The temperature and relative humidity were measured weekly during daytime. During the whole course of exposure, the temperature ranged from 22 to $38^{\circ} \mathrm{C}$, while the relative humidity ranged from 58 to $77 \%$.

Bending test: after 12 months of exposure, the test beams were loaded to failure under 4-point loading, Figure 5. The mid-span deflection was measured at equal load steps of $2.0 \mathrm{kN}$ until the main steel yielded, and then the deflection was measured at specified displacement increments. The load versus the mid-span deflection curves is shown in Figure 6 .

\section{Results and discussion}

The fourteen test specimens were arranged into two sets during long-term exposure. The upper beams (B1-B7) were reference beams, while the lower beams (B1C-B7C) were exposed to corrosive conditions in order to investigate the corrosion resistance of the SCC mixes (M1-M7). Figure 6 shows the relation between the total acting load $(\mathrm{P})$ and the measured mid-span deflection. Table 5 reports the ultimate loads recorded as well as the deflections $\left(\Delta_{y}, \Delta_{u}\right)$ at the yield and ultimate loads. The corresponding values for the ductility index $\left(\Delta_{u} / \Delta_{y}\right)$ as a measure of ductility were also computed. The corrosion resistance behavior of a given mix Mi (used in casting the two beams $\mathrm{B} i$ and $\mathrm{B} i \mathrm{C}$ ) was evaluated on the basis of the following criteria after performing the four-point load test:

1. Comparing the structural performance in terms of stiffness, ultimate loads, ductility and cracking patterns.

2. Visual inspection of the main rebars after removing the concrete cover. 

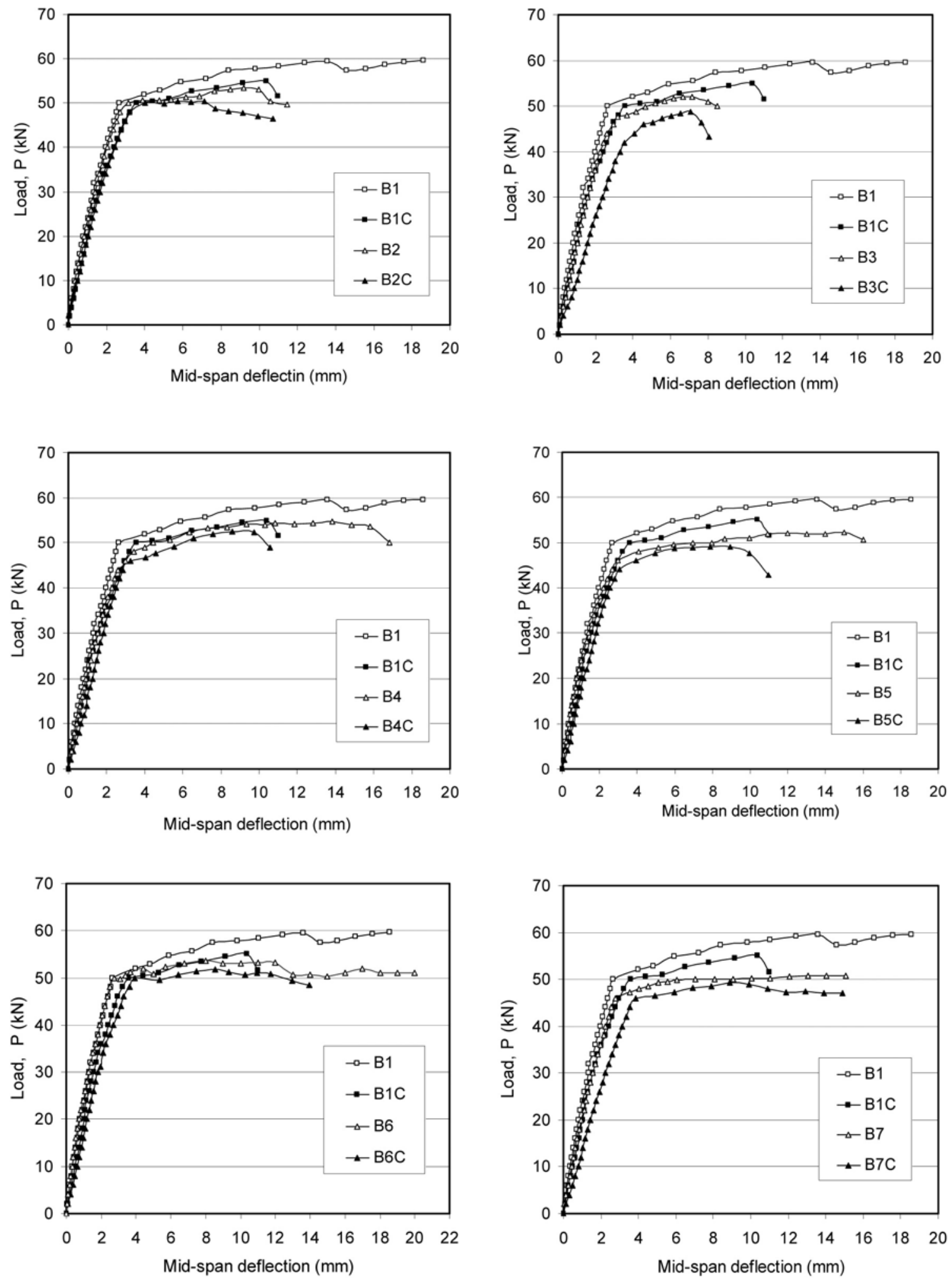

Fig. 6: Load versus mid-span deflection for test beams

Knowing that all test beams were pre-cracked, Figure 6 shows that the load-deflection curves consisted of only two parts: a linear relation up to yield and a yield plateau. The post-cracking stiffness of all test beams subjected to corrosion was smaller than the post-cracking stiffness of the corresponding control beams. A significant reduction in stiffness can be observed in beams B3C (20\% DP) and B7C (30\% $\mathrm{DP}+10 \% \mathrm{FA})$ compared to the stiffness of beams $\mathrm{B} 3$ and B7, respectively. It can be noted that the 
Table 5: Ductility index and ultimate loads recorded for test beams

\begin{tabular}{|c|c|c|c|c|c|c|c|c|c|}
\hline \multicolumn{5}{|c|}{ control beams } & \multicolumn{5}{|c|}{ beams in a corrosive environment } \\
\hline \multirow{2}{*}{ beam } & \multirow{2}{*}{$\begin{array}{c}\text { ultimate load, } \\
\mathrm{kN}\end{array}$} & \multicolumn{2}{|c|}{ deflection, $\mathrm{mm}$} & \multirow{2}{*}{$\begin{array}{l}\text { ductility } \\
\text { index }\end{array}$} & \multirow{2}{*}{ beam } & \multirow{2}{*}{$\begin{array}{c}\text { ultimate load, } \\
\mathrm{kN}\end{array}$} & \multicolumn{2}{|c|}{ deflection, $\mathrm{mm}$} & \multirow{2}{*}{$\begin{array}{c}\text { ductility } \\
\text { index }\end{array}$} \\
\hline & & $\Delta_{y}{ }^{\mathrm{b}}$ & $\Delta_{u}^{\mathrm{b}}$ & & & & $\Delta_{y}{ }^{\mathrm{b}}$ & $\Delta_{u}^{\mathrm{b}}$ & \\
\hline B1 & $59.6(1.00)^{\mathrm{a}}$ & 2.66 & 18.58 & 7.0 & $\mathrm{~B} 1 \mathrm{C}$ & $55.0(0.92)$ & 3.59 & 10.38 & 2.9 \\
\hline $\mathrm{B} 2$ & $53.1(0.89)$ & 3.14 & 9.98 & 3.2 & $\mathrm{~B} 2 \mathrm{C}$ & $50.4(0.85)$ & 3.21 & 7.12 & 2.2 \\
\hline B3 & $52.0(0.87)$ & 3.17 & 7.17 & 2.3 & B3C & $48.7(0.82)$ & 3.55 & 7.05 & 2.0 \\
\hline B4 & $54.8(0.92)$ & 3.00 & 13.8 & 4.6 & $\mathrm{~B} 4 \mathrm{C}$ & $52.3(0.89)$ & 2.88 & 9.70 & 3.4 \\
\hline B5 & $52.2(0.88)$ & 2.95 & 15.00 & 5.1 & $\mathrm{~B} 5 \mathrm{C}$ & $49.1(0.82)$ & 3.03 & 8.96 & 3.0 \\
\hline B6 & $53.0(0.89)$ & 2.75 & 17.00 & 6.2 & B6C & $51.7(0.87)$ & 3.94 & 8.54 & 2.2 \\
\hline B7 & $50.8(0.85)$ & 2.77 & 15.05 & 5.4 & B7C & $49.3(0.83)$ & 3.86 & 8.9 & 2.3 \\
\hline
\end{tabular}

${ }^{\mathrm{a}}(\mathrm{)}$ : ultimate load as a fraction of the ultimate load of the control beam (B1)

b $\Delta_{y}, \Delta_{u}$ : mid-span deflection at yield and ultimate load, respectively

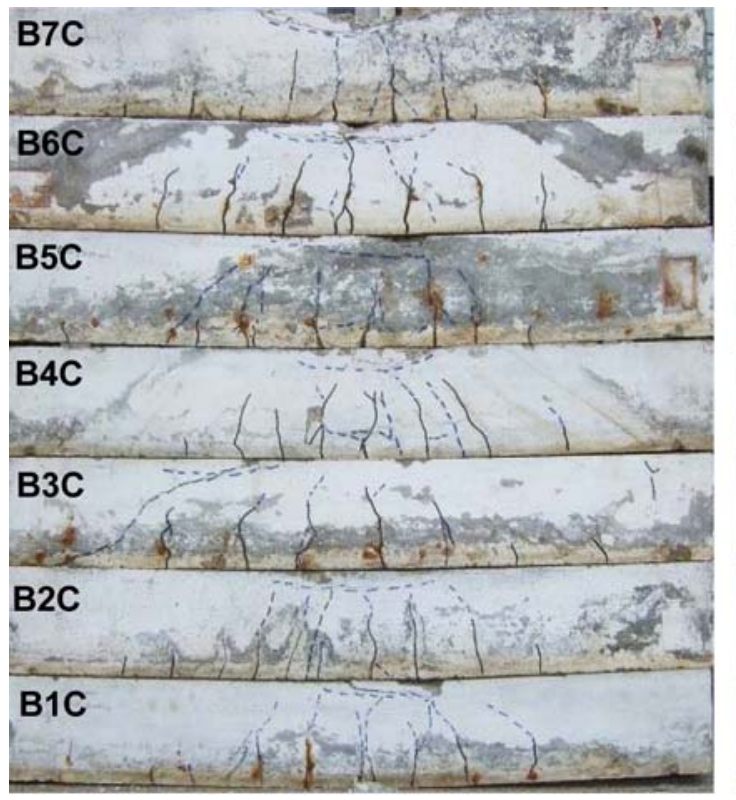

(a) beams in Corrosive environment

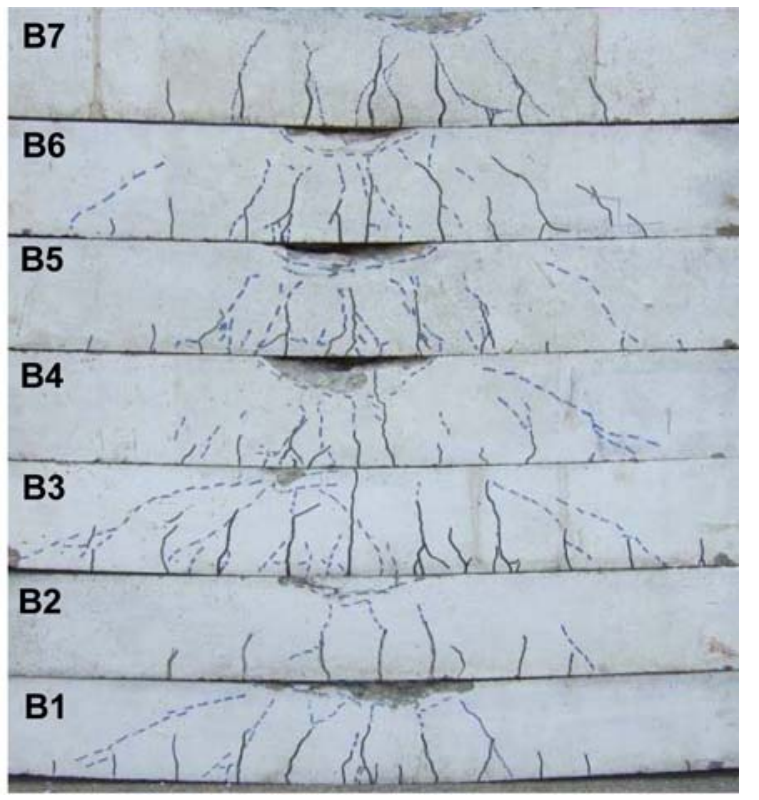

(b) control beams

Fig. 7: Cracking patterns for test beams under sustained load (continuous lines) and at ultimate loads (dashed lines)

stiffness of beams B3 and B7 is very close to that of the control beam B1. On the other hand, the stiffness reduction in beam $\mathrm{B} 4 \mathrm{C}(20 \% \mathrm{DP}+10 \% \mathrm{SF})$ and $\mathrm{B} 5 \mathrm{C}(30 \% \mathrm{DP}+10 \% \mathrm{SF})$ compared to the stiffness in beams B4 and B5 is insignificant. The results summarized in Table 5 show that the ultimate loads recorded for beams (B2-B7) were 81 to 92 percent of the ultimate load of control beam B1. This reduction in the ultimate load was consistent with the change in the compressive strength of the SCC mixes that were used.

The recorded ultimate loads for beams (B1C-B7C) were very close to the corresponding ultimate loads of beams (B1-B7), and were only $5 \%$ less in average. These results indicated that no serious loss in the area of the main reinforcement occurred under the prescribed exposure conditions. On the other hand, the results suggested that the corrosion affected only the bond characteristics between the steel rebars and concrete. It is well known that a steel-concrete bond is the sum of two components due to adhesion and the interlocking action provided by the ribs. It is here suggested that the bond reduction is mainly related to reduced adhesion between the concrete and the steel rebars, while the ultimate bond strength was adequate so that the test beams (B1C-B7C) developed the reported ultimate loads. The suggestion of the lack of adhesion bond in the corroded beams is consistent with the following observations:

1. A reduction in post-cracking stiffness.

2. A comparison of the cracking patterns in Figure 7 shows that new cracks developed in beams 
(B1-B7) during four-point loading, while this was not the case for the corroded beams. However, beams B4C (20\% DP + $10 \% \mathrm{SF})$ and B5C $(30 \% \mathrm{DP}+10 \% \mathrm{SF})$ were exceptions.

Examining the cracking patterns at failure, Figure 7 , shows that all test beams failed due to concrete crushing in the maximum moment region. However, beams B3C (20\% DP) failed in shear due to the formation of a diagonal tension crack. This premature failure may be related to the lack of bond between the main reinforcement and concrete. The computed ductility index reported in Table 5 shows that control beam B1 had the highest ductility measure. The ductility index was considerably lower in beams B2 and B3, while a better ductility measure was achieved by the rest of the beams (B4-B7) containing $10 \% \mathrm{SF}$ or FA. The ductility index in beams (B1C-B7C) ranged from $35 \%$ to $87 \%$ of the corresponding values recorded for the corresponding control beams (B1-B7), indicating limited ductility due to corrosion.

Finally, a visual inspection of the main reinforcement in the corroded beams (B1C-B7C) after conducting the four-point test and removing the concrete cover confirmed the existence of a corroded surface layer in all beams. The corroded surface did not cover the whole length of the bar. The corroded portions covered about $70-100 \mathrm{~mm}$ around the points of intersection of the rebar with the pre-cracks developed under the sustained load. Small and shallow pitting was observed along the main rebars in the corroded beams.

\section{Conclusions}

This research included experimental testing of reinforced concrete beams cast with different SCC mixes incorporating combinations of silica fume, fly ash and dolomite powder as fine materials replacing Portland cement. All test beams were stored under sustained load that caused the beams to crack to simulate actual exposure conditions. Half of the beams were exposed to a harsh environment, while the other half were similar control beams. After one year of exposure, the corrosion resistance provided by the different SCC mixes was evaluated on the basis of the structural performance of the test beams in flexure compared to the behavior of the control beams. The proposed aggressive environment helped to initiate corrosion along the main rebars. No severe reduction in the area of the main reinforcement was detected, and only small and shallow pitting was observed. Based on the available test results, the following conclusions can be drawn:

1. Independent of the SCC mix composition, the structural performance of the tested control beams was quite similar in terms of post- cracking stiffness and mode of failure. The variation in the ultimate loads was consistent with the variation in the compressive strength of the SCC mixes that were used.

2. The ductility index of the control beams was considerably lower than that of the control beam containing only Portland cement. The addition of either silica fume or fly ash effectively increased the ductility index.

3. The post cracking stiffness of the corroded beams was significantly less in the beam containing $20 \%$ dolomite powder as a cement replacement. The use of $10 \%$ silica fume was effective in increasing the post-cracking stiffness, even when the dolomite powder replacement increased to 30 percent.

4. All corroded beams showed a reduction in the ductility index compared to the corresponding control beams. The use of silica fume yielded a relatively higher ductility index.

5. The use of silica fume was found to be more effective than fly ash for improving the structural performance in terms of ductility and postcracking stiffness for corrosion-exposed SCC beams containing up to 30 percent dolomite powder replacing Portland cement.

\section{References}

[1] ACI Committee 222: Protection of metals in concrete against corrosion. ACI Manual of Concrete Practice - Part 1: Materials and general properties of concrete, 2008, 41p.

[2] Hoke, J. H., Chama, C., Rosengarth, K.: Measurement of stresses developing during corrosion of embedded concrete reinforcing bars. Corrosion, 1983, Paper No. 168, National Association of Corrosion Engineers, Houston, USA.

[3] Uhlig, H. H.: Corrosion and corrosion control. 2nd Edition, New York, USA : John Wiley \& Sons, 1971, $419 \mathrm{p}$.

[4] ACI Committee 318: Building code requirements for structural concrete. ACI 318, 2005, Michigan, USA, $443 \mathrm{p}$.

[5] Beckett, D.: Influence of carbonation and chloride on concrete durability. Concrete, Feb. 1983, p. $16-18$.

[6] Pettersson, K.: Chloride threshold value and the corrosion rate in reinforced concrete. Cement and Concrete Research, 20, 1994, p. 461-470.

[7] PCA Report IS536: Types and causes of concrete deterioration. Portland Cement Ass., Illinois, USA, 6 p. 
[8] ACI 234R-06: Guide for the use of silica fume in concrete. ACI Manual of Concrete Practice Part 1: Materials and general properties of concrete, 2008, $51 \mathrm{p}$.

[9] ACI Committee 201.2R-01. Guide to durable concrete. ACI Manual of Concrete Practice Part 1: Materials and Properties of Concrete, 2008, 51 p.

[10] Ozawa, K., Maekawa, K., Kunishima, M., Okamura, H.: Development of high performance concrete based on durability design of concrete structures. $2^{\text {nd }}$ East-Asia and Pacific Conference on Structure Engineering and Construction, Kochi, Japan, 1988, p. 445-450.

[11] Okamura, H., Ouchi, M.: Self-compacting concrete. Journal of Advanced Concrete Technology, 1, 2003, p. 5-15.

[12] Okamura, H., Ozawa, K.: Mix-design for selfcompacting concrete, Concrete Library of JSCE, 25, 1995, p. 107-120.

[13] ACI 237R-07: Self-consolidating concrete. ACI Manual of Concrete Practice - Part 1: Materials and general properties of concrete, 2008, 34 p.

[14] Mindess, S.: Bonding in cementitious composites: How important is it, Proceedings of the Bonding in Cementitious Composites Symposium, Boston, 1988, pp. 3-10.

[15] ASTM C618: Specification for fly ash and raw calcined natural pozzolan for use as a mineral admixture in Portland cement concrete, Annual Book for ASTM Stand, 4, 2000, 4 p.

[16] ACI 232.2R-03: Use of fly ash in concrete. ACI Manual of Concrete Practice - Part 1: Materials and general properties of concrete, 2008, 41 p.

[17] Ye, G., Liu, X., De Schutter, G., Poppe, A., Taerwe, L.: Influence of limestone powder used as filler in SCC on hydration and microstructure of cement pastes, Cement and Concrete Composites, 29, 2007, pp. 94-102.

[18] Yazici, H.: The effect of silica fume and high-volume class C-fly ash on mechanical properties, chloride penetration and freezethaw resistance of self-compacting concrete. Construction and Building Materials, 2007, doi:10.1016/J.conbuildmat 2007.01.002.
[19] Assié, S., Escadeillas, G., Waller, V.: Estimates of self-compacting concrete potential durability, Construction and Building Materials, 21, 2007, p. 1909-1917.

[20] Zhu, W., Bartos, P.: Permeation properties of self-compacting concrete, Cement and Concrete Rearch, 33, 2003, p. 921-926.

[21] Saylev, T. A., Francois, R.: Quality of steelconcrete interface and corrosion of reinforcing steel, Cement and Concrete Research, 33, 2003, p. $1407-1415$.

[22] Mehta, P. K., Burrows, R. W.: Building durable structures in the $21^{\text {st }}$ century, Concrete International, 2001, p. 57-63.

[23] Naik, T. R., Kraus, R. N., Chun, Y., Canpolat, F., Ramme, B. W.: Use of lime stone quarry by-products for developing economical self-compacting concrete. CANMET/ACI (SDCC 38) International Symposium on Sustainable Development of Cement and Concrete, 2005, Canada, 21 p.

[24] Elinwa, A. U., Ejeh, S. P., Mamuda, A. M.: Assessing of the fresh concrete properties of selfcompacting concrete containing sawdust ash, Construction and Building Materials, 2007, doi:10.1016/J.conbuildmat 2007.02.004.

[25] Kamal, M. M., Safan, M. A., Al-gazzar, M. A.: Blended Portland cements for low-cost selfcompacting concrete, Proceedings of the $1^{\text {st }}$ International Conference "New Cements and their Effects on Concrete Performance", National Housing and Building and Research Center, Egypt, 2008, 12 p.

[26] BS-EN 197-1: Cement: composition, specifications, and conformity criteria for common cements. 2000, 52 p.

Mohamad A. Safan

Phone: 0020104919 623, Fax. 0020482328405

E-mail: msafan2000@yahoo.com

Department of Civil Engineering

Engineering Faculty

Menoufia University

Shebeen el-koom, Menoufia, Egypt 